\title{
PIK3CA mutation, reduced AKT serine 473 phosphorylation, and increased ERa serine 167 phosphorylation are positive prognostic indicators in postmenopausal estrogen receptor-positive early breast cancer
}

\author{
Naoko Ishida', Motoi Baba¹, Yutaka Hatanaka2,3, Kanako Hagio1, Hiromi Okada ${ }^{2}$, \\ Kanako C. Hatanaka ${ }^{3}$, Kenichi Togashi ${ }^{4}$, Yoshihiro Matsuno ${ }^{2,3}$ and Hiroko Yamashita ${ }^{1}$ \\ ${ }^{1}$ Department of Breast Surgery, Hokkaido University Hospital, Kita-ku, Sapporo 060-8648, Japan \\ ${ }^{2}$ Department of Surgical Pathology, Hokkaido University Hospital, Kita-ku, Sapporo 060-8648, Japan \\ ${ }^{3}$ Research Division of Companion Diagnostics, Hokkaido University Hospital, Kita-ku, Sapporo 060-8648, Japan \\ ${ }^{4}$ Roche Diagnostics K.K., Konan, Minato-ku, Tokyo 108-0075, Japan \\ Correspondence to: Hiroko Yamashita, email: hirokoy@huhp.hokudai.ac.jp \\ Keywords: breast cancer; estrogen receptor; PIK3CA; AKT Ser473; ERa Ser167 \\ Received: June 27, $2017 \quad$ Accepted: February 28, $2018 \quad$ Published: April 03, 2018 \\ Copyright: Ishida et al. This is an open-access article distributed under the terms of the Creative Commons Attribution License 3.0 \\ (CC BY 3.0), which permits unrestricted use, distribution, and reproduction in any medium, provided the original author and source \\ are credited.
}

\section{ABSTRACT}

Although endocrine therapy is the most important treatment option in estrogen receptor (ER)-positive breast cancer, new strategies, such as molecular targeted agents together with endocrine therapy are required to improve survival. PIK3CA is the most frequent mutated gene in ER-positive early breast cancers, and PIK3CA mutation status is reported to affect activation of AKT and ERa. Moreover, recent studies demonstrate that patients had a better prognosis when tumors expressed ER, androgen receptor (AR), and vitamin D receptor (VDR). In this study, we examined expression of AR and VDR, phosphorylation of AKT serine (Ser) 473 (AKT phosphoSer473) and ERa Ser167 (ERa phospho-Ser167) by immunohistochemistry in ERpositive, HER2-negative early breast cancer. PIK3CA gene mutations were also detected in genomic DNA extracted from tumor blocks. Correlations between these biological markers, clinicopathological factors and prognosis were analyzed. Levels of AKT phospho-Ser473 were significantly higher in premenopausal women than in postmenopausal women. In contrast, AR expression was significantly higher in postmenopausal women than in premenopausal women. PIK3CA mutations were detected in $47 \%$ in premenopausal women and $47 \%$ in postmenopausal women. Postmenopausal women with PIK3CA wild-type tumors had significantly worse disease-free survival than patients with PIK3CA mutant tumors. Low levels of AKT phospho-Ser473 and high levels of ERa phospho-Ser167 were strongly associated with increased disease-free survival in postmenopausal women. Evaluation of ERa activation, in addition to PIK3CA mutation status, might be helpful in identifying patients who are likely to benefit from endocrine therapy alone versus those who are not in postmenopausal ER-positive early breast cancer.

\section{INTRODUCTION}

Endocrine therapy is the most important treatment option for women with estrogen receptor (ER)-positive breast cancer $[1,2]$. Nevertheless, many early breast cancer patients with tumors expressing high levels of ER relapse after initial treatments, including adjuvant endocrine therapy. We recently identified predictors of early and late distant recurrence following an analysis of clinicopathological factors and adjuvant therapies among patients with early and 
late distant recurrence and patients without recurrence in ERpositive, HER2-negative breast cancer [3]. Approximately two-thirds of patients who relapsed within 5 years had received anthracyclins and/or taxanes as adjuvant or neoadjuvant chemotherapy, in addition to adjuvant endocrine therapy. Thus, new strategies, such as those deploying inhibitors of oncogenic driver proteins together with endocrine therapy are required to improve survival.

Mutations of the phosphatidylinositol-4,-5bisphosphate 3-kinase catalytic subunit alpha (PIK3CA) gene are one of the most frequent genetic alterations in breast cancer $[4,5]$. The Cancer Genome Atlas Network reported that $P I K 3 C A$ is the most frequent mutated gene in the luminal A (49\%) and luminal B (32\%) breast cancer subtypes [4]. Almost $95 \%$ of mutations occur within the helical domain (exon 9, commonly E542 and E545) and the kinase domain (exon 20, commonly H1047) [6]. A meta-analysis involving 26 studies found a significant association between PIK3CA mutations and expression of ER and progesterone receptor ( $\mathrm{PgR})$, and suggested that the clinical implications of PIK3CA mutations may vary according to the exons harboring the mutation [7]. However, there is currently insufficient evidence to recommend routine genotyping of $P I K 3 C A$ in clinical practice, although many studies have been performed regarding the prognostic and therapeutic implications of PIK3CA mutations in breast cancer [8].

We previously showed that increased phosphorylation of ER $\alpha$ serine (Ser) 167 was associated with an improved survival in ER-positive early breast cancer [9]. Moreover, patients with increased ER $\alpha$ Ser167 phosphorylation in primary breast tumors responded to endocrine therapy, and survived significantly longer after relapse in metastatic breast cancer [10]. ER $\alpha$ Ser167 is phosphorylated by several kinases, including MAPK, AKT, and p90 ribosomal S6 kinase [11]. PIK3CA mutation status might affect phosphorylation of both AKT and ER $\alpha$ Ser167. In addition, our previous study demonstrated that the expression of estrogen and progesterone-responsive genes, ER-related genes and p53 in ER-positive, HER2-negative breast cancer differ between pre- and postmenopausal women. This indicates that menopausal status might affect the development and estrogendependent growth of ER-positive breast cancer [12].

On the other hand, Santagata and colleagues compared 3,157 human breast tumors to normal cell types and divided them into four major subtypes that were differentiated by ER, androgen receptor (AR), and vitamin D receptor (VDR) status [13]. The authors found that patients had a better prognosis when tumors expressed all three receptors. AR is detected in about $30 \%$ of triplenegative breast cancers, and its biological effects have been extensively investigated in this subtype [14]. However, although both AR and VDR are highly expressed in ERpositive breast cancer, their role in disease etiology of this subtype remains poorly understood [15-19].
In this study, we examined expression of AR and VDR, phosphorylation of AKT Ser473 (AKT phosphoSer473) and ER $\alpha$ Ser167 (ER $\alpha$ phospho-Ser167), and the mutational status of the PIK3CA gene in ER-positive, HER2-negative early breast cancer tissues. We then analyzed pre- and postmenopausal women separately to determine whether there were any correlations between these biological markers, clinicopathological factors and prognosis.

\section{RESULTS}

\section{Comparison of expression and phosphorylation of biological markers between pre- and postmenopausal women}

We first examined the expression of Ki67, ER, progesterone receptor (PgR), AR, and VDR and the phosphorylation of AKT Ser473 and ER $\alpha$ Ser167 by immunohistochemistry (IHC) in breast cancer tissues in pre- $(n=62)$ and postmenopausal $(n=152)$ women (Tables 1 and 2, Figure 1). Expression of PgR and levels of AKT phospho-Ser473 were significantly higher in premenopausal women than in postmenopausal women $(P<0.001$ and $P=0.014$, respectively, Table 3 ). In contrast, the expression of AR was significantly higher in postmenopausal women than in premenopausal women $(P<0.001$, Table 3$)$.

\section{PIK3CA mutation frequencies in breast cancer tissues}

We next evaluated the genomic DNA of primary breast cancer specimens for PIK3CA mutations using the cobas ${ }^{\circledR}$ PIK3CA Mutation Test (Table 4). Two tumors (3.2\%) in premenopausal women and 8 tumors $(5.3 \%)$ in postmenopausal women were invalid. Of the 60 tumors that we were able to evaluate in premenopausal women, 31 tumors (51.7\%) had no mutation (wild-type), 26 tumors $(43.3 \%)$ had a single mutation, and 3 tumors $(5.0 \%)$ had mutations at two sites. On the other hand, of the evaluable 144 tumors in postmenopausal women, 73 tumors $(50.7 \%)$ had no mutation (wild-type), 64 tumors $(44.4 \%)$ had a single mutation, 6 tumors $(4.2 \%)$ had mutations at two sites, and one tumor $(0.7 \%)$ had mutations at three sites. Therefore, the frequencies of single and double mutations were similar between pre- and postmenopausal women. The H1047 missense mutation was the most frequent mutation site, being present in 19 tumors $(31.7 \%)$ in premenopausal women and 42 tumors $(29.2 \%)$ in postmenopausal women. E545 was the second most frequent mutation site, and was found in 5 tumors $(8.3 \%)$ among premenopausal women and 18 tumors (12.5\%) among postmenopausal women. Thus, mutation frequencies detected in H1047 and E545 were similar between pre- and postmenopausal women. There were no tumors with R88Q or M1043I mutations in either pre- or postmenopausal women. 
Table 1: Clinicopathological characteristics of patients and tumors in pre- and postmenopausal women

\begin{tabular}{|c|c|c|}
\hline & Premenopausal & Postmenopausal \\
\hline No. of patients & 62 & 152 \\
\hline Age (years), mean \pm SD (range) & $44.2 \pm 5.5(27-56)$ & $63.0 \pm 8.2(42-84)$ \\
\hline $\mathrm{BMI}$, mean $\pm \mathrm{SD}$ (range) & $21.8 \pm 3.7(15.2-32.9)$ & $24.3 \pm 4.3(14.0-40.9)$ \\
\hline \multicolumn{3}{|l|}{ Tumor size } \\
\hline $\mathrm{T} 1(\leq 2.0 \mathrm{~cm})$ & $47(75.8 \%)$ & $102(67.1 \%)$ \\
\hline $\mathrm{T} 2(2.1-5.0 \mathrm{~cm})$ & $13(21.0 \%)$ & $45(29.6 \%)$ \\
\hline $\mathrm{T} 3(>5.0 \mathrm{~cm})$ & $2(3.2 \%)$ & $5(3.3 \%)$ \\
\hline \multicolumn{3}{|l|}{ No. of positive lymph nodes } \\
\hline 0 & $42(67.7 \%)$ & $113(74.3 \%)$ \\
\hline $1-3$ & $14(22.6 \%)$ & $25(16.4 \%)$ \\
\hline$\geq 4$ & $4(6.5 \%)$ & $9(5.9 \%)$ \\
\hline Unknown & $2(3.2 \%)$ & $5(3.3 \%)$ \\
\hline \multicolumn{3}{|l|}{ Tumor grade } \\
\hline 1 & $18(29.0 \%)$ & $32(21.1 \%)$ \\
\hline 2 & $37(59.7 \%)$ & $107(70.4 \%)$ \\
\hline 3 & $7(11.3 \%)$ & $13(8.6 \%)$ \\
\hline \multicolumn{3}{|l|}{ Ki67 LI } \\
\hline$<14 \%$ & $40(64.5 \%)$ & $101(66.4 \%)$ \\
\hline $14-30 \%$ & $15(24.2 \%)$ & $41(27.0 \%)$ \\
\hline$>30 \%$ & $7(11.3 \%)$ & $10(6.6 \%)$ \\
\hline \multicolumn{3}{|l|}{ Postoperative adjuvant therapy } \\
\hline None & $4(6.5 \%)$ & $7(4.6 \%)$ \\
\hline Any endocrine therapy & $58(93.5 \%)$ & $145(95.4 \%)$ \\
\hline Tamoxifen alone & $21(36.2 \%)$ & $8(5.5 \%)$ \\
\hline Tamoxifen + LHRH agonist & $25(43.1 \%)$ & 0 \\
\hline LHRH agonist alone & $6(10.3 \%)$ & 0 \\
\hline Tamoxifen + LHRH agonist $\rightarrow$ AI & $1(1.7 \%)$ & 0 \\
\hline Tamoxifen $\rightarrow$ AI & $1(1.7 \%)$ & $1(0.7 \%)$ \\
\hline AI & $4(6.9 \%)$ & $135(93.1 \%)$ \\
\hline $\mathrm{AI} \rightarrow$ Tamoxifen & 0 & $1(0.7 \%)$ \\
\hline Combined endocrine and chemotherapy & $16(25.8 \%)$ & $28(18.4 \%)$ \\
\hline Follow-up (months), mean \pm SD (range) & $76.7 \pm 38.3(6-128)$ & $77.7 \pm 30.6(6-129)$ \\
\hline
\end{tabular}

LI: labeling index; LHRH agonist: luteinizing hormone-releasing hormone agonist; AI: aromatase inhibitor.

\section{Correlation between PIK3CA mutation status and clinicopathological characteristics}

We next examined whether PIK3CA mutation status affected clinicopathological characteristics in pre- and postmenopausal women (Table 5). Invalid tumors were excluded from this analysis. In premenopausal women, patients with PIK3CA wild-type tumors had lower tumor grade, higher ER expression, and lower AR expression when compared to patients with PIK3CA mutant tumors ( $P=0.041, P=0.025$, and $P=0.047$, respectively). On the other hand, in postmenopausal women, patients with 
Table 2: List of antibodies used for immunohistochemical analysis

\begin{tabular}{|c|c|c|c|c|}
\hline & Antibody & Species (dilution) & 2nd antibody & Evaluation \\
\hline ER & $\begin{array}{l}\text { SP1, Ventana Medical } \\
\text { Systems, Tucson, USA }\end{array}$ & $\begin{array}{l}\text { rabbit monoclonal } \\
\text { (prediluted) }\end{array}$ & $\begin{array}{l}\text { Ventana iVIEW DAB } \\
\text { Detection Kit }\end{array}$ & $\begin{array}{l}\text { percentage of cells showing } \\
\text { positive nuclear staining }\end{array}$ \\
\hline PgR & $\begin{array}{l}\text { 1E2, Ventana Medical } \\
\text { Systems, Tucson, USA }\end{array}$ & $\begin{array}{l}\text { rabbit monoclonal } \\
\text { (prediluted) }\end{array}$ & $\begin{array}{l}\text { Ventana iVIEW DAB } \\
\text { Detection Kit }\end{array}$ & $\begin{array}{l}\text { percentage of cells showing } \\
\text { positive nuclear staining }\end{array}$ \\
\hline HER2 & $\begin{array}{l}\text { 4B5, Ventana Medical } \\
\text { Systems, Tucson, USA }\end{array}$ & $\begin{array}{l}\text { rabbit monoclonal } \\
\text { (prediluted) }\end{array}$ & $\begin{array}{l}\text { Ventana iVIEW DAB } \\
\text { Detection Kit }\end{array}$ & $0,1+, 2+, 3+$ \\
\hline Ki67 & $\begin{array}{l}\text { MIB-1, DAKO, } \\
\text { Glostrup, Denmark }\end{array}$ & $\begin{array}{l}\text { mouse monoclonal } \\
(1: 200)\end{array}$ & $\begin{array}{l}\text { Dako EnVison FLEX } \\
\text { system }\end{array}$ & labeling index \\
\hline $\mathrm{AR}$ & $\begin{array}{l}\text { AR27, Novocastra, } \\
\text { Newcastle, UK }\end{array}$ & $\begin{array}{l}\text { mouse monoclonal } \\
(1: 50)\end{array}$ & $\begin{array}{l}\text { Dako EnVison FLEX } \\
\text { system }\end{array}$ & $\begin{array}{l}\text { percentage of cells showing } \\
\text { positive nuclear staining }\end{array}$ \\
\hline VDR & $\begin{array}{l}\text { NBP1-19478, Novus, } \\
\text { Littleton, USA }\end{array}$ & $\begin{array}{l}\text { rabbit polyclonal } \\
(1: 500)\end{array}$ & $\begin{array}{l}\text { Dako EnVison FLEX } \\
\text { system }\end{array}$ & $\begin{array}{l}\text { percentage of cells showing } \\
\text { positive nuclear staining }\end{array}$ \\
\hline $\begin{array}{l}\text { AKT phospho- } \\
\text { Ser473 (pAKT) }\end{array}$ & $\begin{array}{l}\text { D9E, Cell Signaling, } \\
\text { Beverly, USA }\end{array}$ & $\begin{array}{l}\text { rabbit monoclonal } \\
(1: 50)\end{array}$ & $\begin{array}{l}\text { Dako EnVison FLEX } \\
\text { system }\end{array}$ & $\begin{array}{l}\text { percentage of cells and } \\
\text { intensity showing positive } \\
\text { cytoplasmic staining }\end{array}$ \\
\hline $\begin{array}{l}\text { ER } \alpha \text { phospho- } \\
\text { Ser167 (pER) }\end{array}$ & $\begin{array}{l}\text { GTX50140, GeneTex, } \\
\text { Irvine, USA }\end{array}$ & $\begin{array}{l}\text { rabbit polyclonal } \\
(1: 50)\end{array}$ & $\begin{array}{l}\text { Dako EnVison FLEX } \\
\text { system }\end{array}$ & $\begin{array}{l}\text { percentage of cells showing } \\
\text { positive nuclear staining }\end{array}$ \\
\hline
\end{tabular}

PIK3CA wild-type tumors had higher Ki67 LI, higher AKT phospho-Ser473, and lower ER $\alpha$ phospho-Ser167 when compared to patients with $P I K 3 C A$ mutant tumors ( $P=0.03, P=0.0049$, and $P=0.018$, respectively).

\section{Biological predictors of survival in postmenopausal women}

We then analyzed whether PIK3CA mutation status and phosphorylation of AKT Ser473 or ER $\alpha$ Ser167 affected disease-free survival in postmenopausal women (Figure 2). Postmenopausal women with PIK3CA wild-type tumors had significantly worse disease-free survival than patients with $P I K 3 C A$ mutant tumors $(P=0.007$; Figure $2 \mathrm{~A})$. To identify clinically meaningful cutoff points for levels of AKT phosphor-Ser473 and ER $\alpha$ phospho-Ser167, we performed a Kaplan-Meier analysis and verified by the log-rank test for disease-free survival. The cutoff points for the levels of AKT phosphoSer473 and ER $\alpha$ phospho-Ser167 were set at 170 and $15 \%$, respectively. Kaplan-Meier analysis showed that low AKT phospho-Ser473 was strongly associated with increased disease-free survival compared to high AKT phospho-Ser473 ( $P=0.016$; Figure $2 \mathrm{~B})$. Moreover, high $\mathrm{ER} \alpha$ phospho-Ser167 was significantly associated with increased disease-free survival compared to low ER $\alpha$ phospho-Ser167 ( $P=0.0016$; Figure 2C).
We then analyzed whether clinicopathological and biological markers were associated with altered prognosis of postmenopausal patients with ER-positive, HER2negative breast cancer (Table 6). Univariate analysis demonstrated significant association between improved disease-free survival and low AKT phospho-Ser473 $(P=0.02)$, high ER $\alpha$ phospho-Ser167 $(P=0.02)$ and the presence of $P I K 3 C A$ mutations $(P=0.02)$, as well as negative lymph node status $(P=0.04)$, low tumor grade $(P=0.01)$ and low Ki67 LI $(P<0.001)$. In multivariate analysis, a significant association was observed between disease-free survival and the presence of $P I K 3 C A$ mutations $(P=0.02)$, as well as negative lymph node status $(P=0.008)$ and low Ki67 LI $(P=0.005)$. Expression of $\mathrm{AR}$ and VDR was not significantly correlated with diseasefree survival in the univariate analysis.

\section{Combining PIK3CA mutation status with the status of AKT Ser473 and ERo Ser167 phosphorylation provides an improved predictor of clinicopathological characteristics and prognosis in postmenopausal women}

We further analyzed correlation whether a combination of PIK3CA mutation status, AKT phosphoSer473 (pAKT) and ER $\alpha$ phospho-Ser167 (pER) had any predictive function with regard to clinicopathological 
characteristics and disease-free survival in postmenopausal ER-positive, HER2-negative breast cancer (Table 7). According to the PIK3CA-pAKT-pER status, we classified PIK3CA wild-type tumors into 4 types (A, B, C, and D) and $P I K 3 C A$ mutant tumors into 3 types $(\mathrm{E}, \mathrm{F}$, and $\mathrm{G})$. From a total of 73 patients with $P I K 3 C A$ wild-type tumors, 21 patients (28\%) had high AKT phospho-Ser473 (Type A or Type B), and 52 patients (72\%) had low AKT phosphoSer473 tumors (Type C or Type D). Tumor grade was significantly higher in Type A (pAKT-high/pER-low) compared with that in Type B (pAKT-high/pER-high) $(P=0.0083)$. PgR expression was significantly lower $(P=0.047)$ and VDR expression was significantly higher $(P=0.032)$ in Type B compared to those in Type $\mathrm{C}$ (pAKT-low/ pER-low). Four (50\%) patients in Type A relapsed within 5 years of the initial treatment, whereas none of the patients in Type D (pAKT-low/pER-high) relapsed within 5 years (Table 7 and Figure $3 \mathrm{~A}, P<$ 0.001). However, one patient in Type $\mathrm{B}$, one patient in Type $\mathrm{C}$ and two patients in Type $\mathrm{D}$ relapsed 5 years after the initial treatment.

Of the 71 patients with $P I K 3 C A$ mutant tumors, 9 patients (13\%) had high AKT phospho-Ser473 (Type E), 21 patients (30\%) had low AKT phospho-Ser473 and low ER $\alpha$ phospho-Ser167 (Type E), and 41 patients (58\%) had low AKT phospho-Ser473 and high ER $\alpha$ phospho-Ser167 tumors (Type G). Age was significantly lower in Type E (pAKT-high) than in Type G (pAKT-low/pER-high) $(P=0.0095)$. On the other hand, tumor size was significantly larger $(P=0.0094)$, and expression of ER and AR was significantly lower in Type F (low pAKT/ low pER) than those in Type $\mathrm{G}(P=0.023$ and $P=0.024$, respectively). All of the patients with Type E or Type $G$ are currently disease-free (Table 7 and Figure 3B). Only three patients (14\%) with PIK3CA mutant tumors, all of whom were classified in Type F, relapsed within 10 years (Table 7 and Figure 3B, $P=0.035$ ).

\section{DISCUSSION}

PIK3CA mutations lead to AKT activation and induce oncogenic transformation in experimental models [20-22]. PI3K pathway activation is suggested to engender resistance to endocrine therapy in ER-positive advanced breast cancer. In support of this, progression-free survival was significantly longer in patients with ctDNA PIK3CA mutations who were treated with a PI3K inhibitor in combination with endocrine therapy compared to those treated with endocrine therapy alone [23]. In contrast, in early breast cancer, previous studies demonstrated that
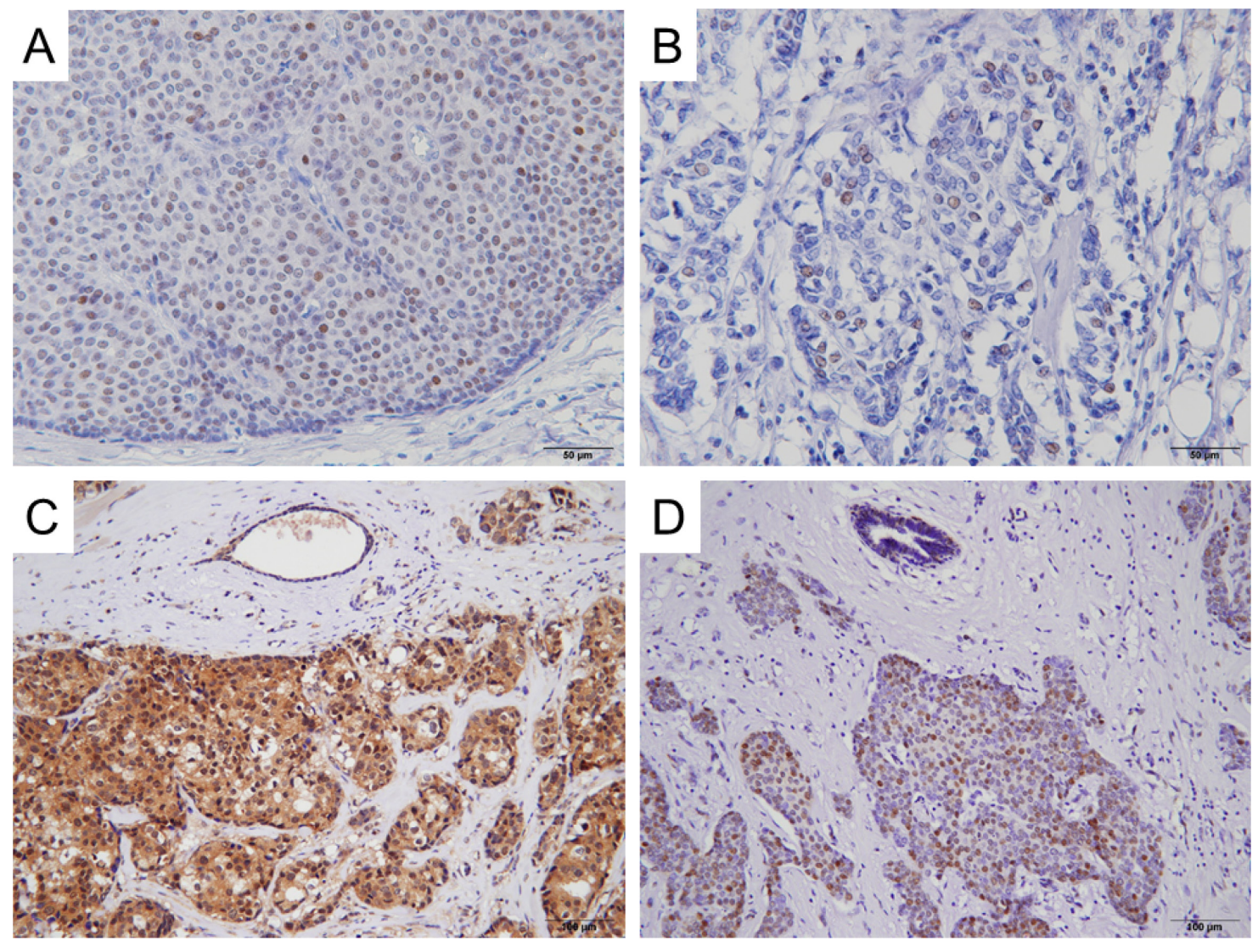

Figure 1: Representative immunohistochemical staining of AR, VDR, AKT Ser473 and ERo Ser167 in invasive ductal carcinoma. Positive nuclear staining of AR (A), VDR (B) and ER $\alpha$ phospho-Ser167 (D), and positive cytoplasmic staining of AKT phospho-Ser473 (C) are seen in carcinoma cells. 
Table 3: Comparison of expression and phosphorylation levels of biological markers between pre- and postmenopausal women

\begin{tabular}{lccc}
\hline & Premenopausal (mean \pm SD) & Postmenopausal (mean \pm SD) & $P$ \\
\hline Ki67 LI (\%) & $14.1 \pm 13.1$ & $11.9 \pm 9.7$ & 0.43 \\
ER (\%) & $76.6 \pm 25.0$ & $81.3 \pm 22.1$ & 0.19 \\
PgR (\%) & $63.5 \pm 36.1$ & $30.2 \pm 32.1$ & $<0.001^{*}$ \\
AR (\%) & $21.9 \pm 25.3$ & $38.5 \pm 31.6$ & $<0.001^{*}$ \\
VDR (\%) & $15.3 \pm 17.7$ & $16.8 \pm 14.9$ & 0.29 \\
pAKT (score) & $127.3 \pm 86.8$ & $94.1 \pm 75.1$ & $0.014^{*}$ \\
pER (\%) & $24.1 \pm 20.9$ & $20.9 \pm 18.7$ & 0.27 \\
\hline
\end{tabular}

LI: labeling index; pAKT: AKT phospho-Ser473; pER: ER $\alpha$ phospho-Ser167.

${ }^{*} P<0.05$ is considered significant.

Table 4: PIK3CA mutation frequencies in breast cancer tissues in pre- and postmenopausal women

\begin{tabular}{|c|c|c|c|c|c|}
\hline & & & & Premenopausal & Postmenopausal \\
\hline No. of patients & & & & 62 & 152 \\
\hline Wild-type & & & & $31(50.0 \%)$ & $73(48.0 \%)$ \\
\hline Mutant & & & & $29(46.8 \%)$ & $71(46.7 \%)$ \\
\hline Invalid & & & & $2(3.2 \%)$ & $8(5.3 \%)$ \\
\hline$P I K 3 C A$ domain & Exon & Nucleotide change & Amino acid mutation & $n=60$ & $n=144$ \\
\hline Single mutation & & & & $26(43.3 \%)$ & $64(44.4 \%)$ \\
\hline $\begin{array}{l}\text { p85-regulatory } \\
\text { subunit- binding }\end{array}$ & 1 & $263 \mathrm{G}>\mathrm{A}$ & R88Q & 0 & 0 \\
\hline \multirow[t]{2}{*}{$\mathrm{C} 2$} & 4 & $1035 \mathrm{~T}>\mathrm{A}$ & $\mathrm{N} 345 \mathrm{~K}$ & $2(3.3 \%)$ & $6(4.2 \%)$ \\
\hline & 7 & $1258 \mathrm{~T}>\mathrm{C}$ & $\mathrm{C} 420 \mathrm{R}$ & $1(1.7 \%)$ & $2(1.4 \%)$ \\
\hline \multirow[t]{3}{*}{ Helical } & 9 & $1624 \mathrm{G}>\mathrm{A}$ & E542K & $2(3.3 \%)$ & $1(0.7 \%)$ \\
\hline & 9 & $\begin{array}{c}1634 \mathrm{~A}>\mathrm{C}^{\mathrm{a})}, 1635 \mathrm{G}>\mathrm{T}^{\mathrm{b})} \\
1634 \mathrm{~A}>\mathrm{G}^{\mathrm{c})}, \text { or } \\
1633 \mathrm{G}>\mathrm{A}^{\mathrm{d})}\end{array}$ & $\begin{array}{c}\mathrm{E} 545 \mathrm{X} \\
\left(\mathrm{E} 545 \mathrm{~A}^{\mathrm{a})}, \mathrm{E} 545 \mathrm{D}^{\mathrm{b})},\right. \\
\left.\mathrm{E} 545 \mathrm{G}^{\mathrm{c}}, \text { or } \mathrm{E} 545 \mathrm{~K}^{\mathrm{d})}\right)\end{array}$ & $4(6.7 \%)$ & $15(10.4 \%)$ \\
\hline & 9 & $\begin{array}{c}1636 \mathrm{C}>\mathrm{G}^{\mathrm{e})}, 1636 \mathrm{C}>\mathrm{A}^{\mathrm{f})}, \\
1637 \mathrm{~A}>\mathrm{T}^{\mathrm{g})}, \text { or } \\
1637 \mathrm{~A}>\mathrm{G}^{\mathrm{h})}\end{array}$ & 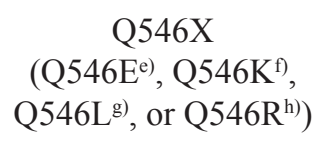 & 0 & $1(0.7 \%)$ \\
\hline \multirow[t]{3}{*}{ Kinase } & 20 & $3129 \mathrm{G}>\mathrm{T}$ & M1043I & 0 & 0 \\
\hline & 20 & $\begin{array}{l}3140 \mathrm{~A}>\mathrm{T}^{\mathrm{i})}, 3140 \mathrm{~A}>\mathrm{G}^{\mathrm{j})} \\
\quad \text { or } 3139 \mathrm{C}>\mathrm{T}^{\mathrm{k})}\end{array}$ & $\begin{array}{c}\mathrm{H} 1047 \mathrm{X} \\
\left(\mathrm{H} 1047 \mathrm{~L}^{\mathrm{i})}, \mathrm{H} 1047 \mathrm{R}^{\mathrm{j}}\right) \\
\left.\text { or } \mathrm{H} 1047 \mathrm{Y}^{\mathrm{k})}\right)\end{array}$ & $17(28.3 \%)$ & $38(26.4 \%)$ \\
\hline & 20 & $3145 \mathrm{G}>\mathrm{C}$ & G1049R & 0 & $1(0.7 \%)$ \\
\hline
\end{tabular}




\begin{tabular}{lccc}
\hline Double mutations & & $3(5.0 \%)$ & $6(4.2 \%)$ \\
\hline C2 and kinase & N345K, H1047X & 0 & $1(0.7 \%)$ \\
Helical and kinase & E542K, H1047X & $1(1.7 \%)$ & $2(1.4 \%)$ \\
& E545X, G1047X & $1(1.7 \%)$ & $2(1.4 \%)$ \\
& E545X, G1049R & 0 & $1(0.7 \%)$ \\
\hline Triple mutations & Q546X, H1047X & $1(1.7 \%)$ & 0 \\
\hline Helical and kinase & & 0 & $1(0.7 \%)$ \\
\hline
\end{tabular}

Table 5: Correlation between $P I K 3 C A$ mutation status and clinicopathological factors in pre- and postmenopausal women

\begin{tabular}{|c|c|c|c|c|c|c|}
\hline & \multicolumn{3}{|c|}{ Premenopausal } & \multicolumn{3}{|c|}{ Postmenopausal } \\
\hline & $\begin{array}{l}\text { Wild-type } \\
\quad(n=31)\end{array}$ & $\begin{array}{l}\text { Mutant } \\
(n=29)\end{array}$ & $P$ & $\begin{array}{l}\text { Wild-type } \\
\quad(n=73)\end{array}$ & $\begin{array}{l}\text { Mutant } \\
(n=71)\end{array}$ & $P$ \\
\hline $\begin{array}{l}\text { Age (years), } \\
\text { mean } \pm \mathrm{SD} \\
\text { (range) }\end{array}$ & $\begin{array}{c}43.2 \pm 5.9 \\
(27-52)\end{array}$ & $\begin{array}{c}45.4 \pm 5.1 \\
(35-56)\end{array}$ & 0.17 & $\begin{array}{c}62.0 \pm 8.2 \\
(42-80)\end{array}$ & $\begin{array}{c}63.8 \pm 8.2 \\
(47-84)\end{array}$ & 0.18 \\
\hline $\begin{array}{l}\mathrm{BMI}, \\
\text { mean } \pm \mathrm{SD} \\
(\text { range) }\end{array}$ & $\begin{array}{c}21.8 \pm 4.1 \\
(15.2-32.9)\end{array}$ & $\begin{array}{l}21.8 \pm 3.4 \\
(16.7-32)\end{array}$ & 0.63 & $\begin{array}{l}24.6 \pm 4.4 \\
(14-38.4)\end{array}$ & $\begin{array}{c}23.8 \pm 4.1 \\
(14.2-40.9)\end{array}$ & 0.38 \\
\hline $\begin{array}{l}\text { Tumor size }(\mathrm{T}) \text {, } \\
\text { median (range) }\end{array}$ & $1(1-2)$ & $1(1-3)$ & 0.56 & $1(1-3)$ & $1(1-3)$ & 0.34 \\
\hline $\begin{array}{l}\text { No. of positive } \\
\text { lymph nodes, } \\
\text { median (range) }\end{array}$ & $0(0-23)$ & $0(0-20)$ & 0.30 & $0(0-10)$ & $0(0-10)$ & 0.90 \\
\hline $\begin{array}{l}\text { Tumor grade, } \\
\text { median (range) } \\
\text { mean } \pm \text { SD }\end{array}$ & $\begin{array}{c}2(1-3) \\
1.7 \pm 0.6\end{array}$ & $\begin{array}{c}2(1-3) \\
2.0 \pm 0.6\end{array}$ & $0.041^{*}$ & $\begin{array}{c}2(1-3) \\
2.0 \pm 0.5\end{array}$ & $\begin{array}{c}2(1-3) \\
1.8 \pm 0.6\end{array}$ & 0.051 \\
\hline $\begin{array}{l}\text { Ki67 LI (\%), } \\
\text { median (range) } \\
\text { mean } \pm \text { SD }\end{array}$ & $\begin{array}{c}10.1 \\
(0-62.7) \\
13.3 \pm 13.6\end{array}$ & $\begin{array}{c}12.2 \\
(1.2-61.3) \\
15.1 \pm 13.1\end{array}$ & 0.46 & $\begin{array}{c}10.3 \\
(2.0-52.7) \\
13.7 \pm 10.3\end{array}$ & $\begin{array}{c}7.5 \\
(0.1-35.3) \\
10.2 \pm 8.1\end{array}$ & $0.03^{*}$ \\
\hline $\begin{array}{l}\mathrm{ER}(\%) \\
\text { median (range) } \\
\text { mean } \pm \mathrm{SD}\end{array}$ & $\begin{array}{c}90 \\
(40-100) \\
83.2 \pm 18.9\end{array}$ & $\begin{array}{c}80 \\
(10-100) \\
68.6 \pm 29.1\end{array}$ & $0.025^{*}$ & $\begin{array}{c}90 \\
(10-100) \\
79.9 \pm 24.1\end{array}$ & $\begin{array}{c}90 \\
(20-100) \\
83.1 \pm 20.3\end{array}$ & 0.40 \\
\hline $\begin{array}{l}\operatorname{PgR}(\%) \\
\text { median (range) } \\
\text { mean } \pm \mathrm{SD}\end{array}$ & $\begin{array}{c}90 \\
(0-100) \\
65.5 \pm 37.0\end{array}$ & $\begin{array}{c}80 \\
(0-100) \\
62.8 \pm 34.7\end{array}$ & 0.44 & $\begin{array}{c}10 \\
(0-100) \\
27.7 \pm 32.1\end{array}$ & $\begin{array}{c}20 \\
(0-100) \\
30.9 \pm 31.1\end{array}$ & 0.37 \\
\hline $\begin{array}{l}\mathrm{AR}(\%), \\
\text { median (range) } \\
\text { mean } \pm \mathrm{SD}\end{array}$ & $\begin{array}{c}1.0 \\
(0-80) \\
17.4 \pm 23.4\end{array}$ & $\begin{array}{c}20 \\
(1-90) \\
28.0 \pm 26.8\end{array}$ & $0.047^{*}$ & $\begin{array}{c}30 \\
(0-95) \\
33.0 \pm 28.9\end{array}$ & $\begin{array}{c}35 \\
(0-100) \\
43.6 \pm 33.8\end{array}$ & 0.065 \\
\hline
\end{tabular}




\begin{tabular}{|c|c|c|c|c|c|c|}
\hline $\begin{array}{l}\text { VDR }(\%), \\
\text { median (range) } \\
\text { mean } \pm \text { SD }\end{array}$ & $\begin{array}{c}10 \\
(0-95) \\
15.4 \pm 17.9\end{array}$ & $\begin{array}{c}10 \\
(0-70) \\
16.2 \pm 17.9\end{array}$ & 0.91 & $\begin{array}{c}10 \\
(0-80) \\
15.7 \pm 16.4\end{array}$ & $\begin{array}{c}20 \\
(0-50) \\
18.0 \pm 13.1\end{array}$ & 0.13 \\
\hline $\begin{array}{l}\text { pAKT (score), } \\
\text { median (range) } \\
\text { mean } \pm \text { SD }\end{array}$ & $\begin{array}{c}120 \\
(0-300) \\
146.5 \pm 93.4\end{array}$ & $\begin{array}{c}100 \\
(0-230) \\
105.5 \pm 76.9\end{array}$ & 0.14 & $\begin{array}{c}100 \\
(0-300) \\
110.2 \pm 79.1\end{array}$ & $\begin{array}{c}70 \\
(0-290) \\
75.5 \pm 65.8\end{array}$ & $0.0049^{*}$ \\
\hline $\begin{array}{l}\mathrm{pER}(\%), \\
\text { median (range) } \\
\text { mean } \pm \mathrm{SD}\end{array}$ & $\begin{array}{c}20 \\
(0-90) \\
25.0 \pm 21.3\end{array}$ & $\begin{array}{c}20 \\
(1-95) \\
23.1 \pm 21.5\end{array}$ & 0.74 & $\begin{array}{c}15 \\
(0-90) \\
17.8 \pm 17.8\end{array}$ & $\begin{array}{c}20 \\
(0-90) \\
23.4 \pm 18.0\end{array}$ & $0.018^{*}$ \\
\hline
\end{tabular}

LI: labeling index; pAKT: AKT phospho-Ser473; pER: ER $\alpha$ phospho-Ser167.

${ }^{*} P<0.05$ is considered significant.

A

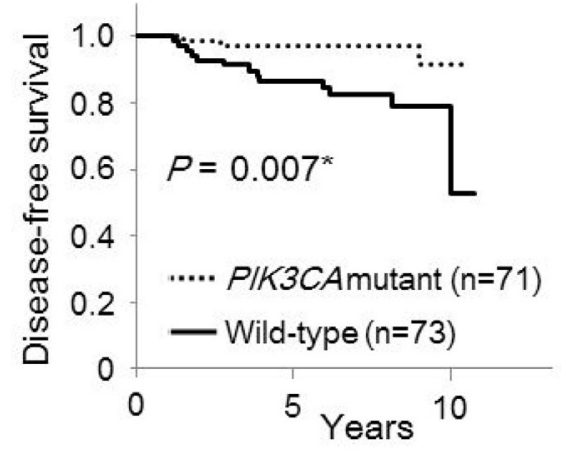

B

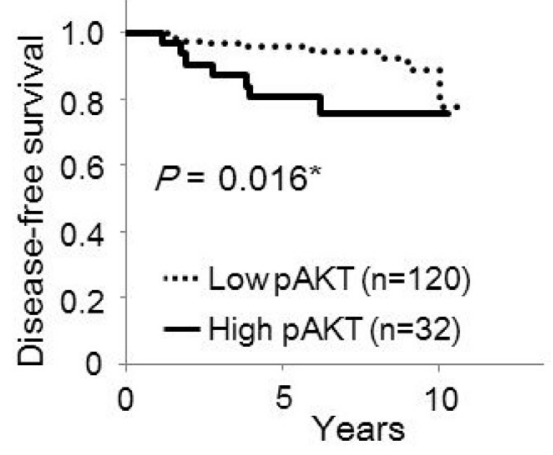

C

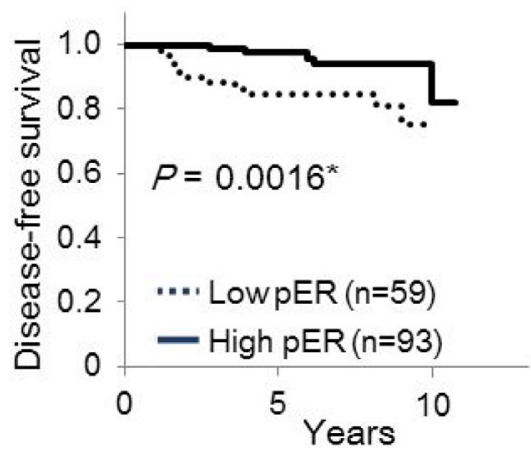

Figure 2: Kaplan-Meier curves of the effect of PIK3CA mutations, phosphorylation of AKT Ser473 and ER $\alpha$ Ser167 on disease-free survival in postmenopausal women. Disease-free survival according to PIK3CA mutations (A), phosphorylation of AKT Ser473 (B), and phosphorylation of ER $\alpha \operatorname{Ser} 167$ (C). 
Table 6: Univariate and multivariate analysis of factors predicting disease-free survival in postmenopausal women

\begin{tabular}{lcccccc}
\hline \multirow{2}{*}{ Factor } & \multicolumn{3}{c}{ Univariate } & \multicolumn{3}{c}{ Multivariate } \\
\cline { 2 - 6 } & $\mathbf{R R}^{\mathrm{a}}$ & $\mathbf{9 5 \%} \mathbf{C I}^{\mathrm{b}}$ & $\boldsymbol{P}$ & $\mathbf{R R}^{\mathrm{a}}$ & $\mathbf{9 5 \%} \mathbf{C I}^{\mathrm{b}}$ & $\boldsymbol{P}$ \\
\hline BMI & 1.02 & $0.91-1.15$ & 0.68 & & & \\
Tumor size & 2.3 & $1.00-5.27$ & 0.05 & & & $0.008^{*}$ \\
Lymph node status & 1.65 & $1.01-2.69$ & $0.04^{*}$ & 1.46 & $1.10-1.93$ & 0.84 \\
Tumor grade & 3.3 & $1.31-8.34$ & $0.01^{*}$ & 1.13 & $0.33-3.95$ & $0.05^{*}$ \\
Ki67 LI & 1.07 & $1.03-1.11$ & $<0.001^{*}$ & 1.05 & $1.02-1.12$ & \\
ER & 1.01 & $0.99-1.04$ & 0.40 & & & \\
PgR & 0.98 & $0.96-1.00$ & 0.05 & & & 0.05 \\
AR & 1.00 & $0.98-1.01$ & 0.71 & & & 0.14 \\
VDR & 1.00 & $0.95-1.02$ & 0.53 & & & $0.02^{*}$ \\
pAKT $(<170,170 \geq)$ & 3.17 & $1.18-8.54$ & $0.02^{*}$ & 0.27 & $0.07-1.01$ & $0.73-8.51$ \\
pER $(<15 \%, 15 \% \geq)$ & 0.27 & $0.09-0.79$ & $0.02^{*}$ & 2.49 & $0.03-0.76$ & \\
PIK3CA mutation & 0.21 & $0.06-0.73$ & $0.02^{*}$ & 0.14 & & \\
Adjuvant chemotherapy & 0.77 & $0.10-5.84$ & 0.80 & & & \\
Adjuvant endocrine therapy & 1.5 & $0.48-4.66$ & 0.48 & & &
\end{tabular}

LI: labeling index; pAKT: AKT phospho-Ser473; pER: ER $\alpha$ phospho-Ser167.

aRelative risk.

${ }^{\mathrm{b}}$ Confidence interval.

${ }^{*} P<0.05$ is considered significant.

PIK3CA mutations were associated with a good prognosis in ER-positive, HER2-negative breast cancer [24]. Sabine and colleagues reported that mutations in PIK3CA were identified in almost $40 \%$ of the 4,294 postmenopausal patients with ER-positive breast cancer who participated in the TEAM trial, whereas the frequency of AKT1 mutation was $3.2 \%$ [25]. They also demonstrated that patients with PIK3CA mutant tumors were at a significantly lower risk of distant metastases at 5 years compared to patients without PIK3CA mutations. Loi and colleagues showed that in ER-positive, HER2-negative, PIK3CA mutant breast cancers, despite apparent PI3K/AKT pathway activation, downstream mTOR1 signaling was not greatly elevated at the transcriptional and biological levels. One of their hypotheses for underlying the mechanism is that PIK3CA mutations are associated with weak pathway activation, and that other PI3K pathway alterations produce stronger pathway activation [24].

Here, we showed that the levels of ER $\alpha$ phosphoSer167 were significantly higher in postmenopausal ERpositive, HER2-negative breast cancers that harbored PIK3CA mutations when compare to their wild-type counterparts. Moreover, ER $\alpha$ phospho-Ser167 is associated with good prognosis. Thus, PIK3CA mutation seems to be associated with phosphorylation of ER $\alpha$
Ser167 and a response to endocrine therapy. Moreover, ER $\alpha$ Ser167 phosphorylation may not be due to activation of the AKT-mTOR pathway, but rather a consequence of activation of factors downstream of PIK3CA mutation. We suggest that PIK3CA is one of the key driver genes for estrogen-dependent progression in postmenopausal ERpositive early breast cancer.

On the other hand, in premenopausal women, the levels of AKT phospho-Ser473 or ER $\alpha$ phospho-Ser167 were not correlated with PIK3CA mutation status. This was, despite the presence of PIK3CA mutations in almost $50 \%$ of premenopausal ER-positive, HER2-negative breast cancer, a frequency identical to that in postmenopausal women. Furthermore, the levels of AKT phospho-Ser473 were significantly higher in premenopausal women compared to those in postmenopausal women, although the levels of ER $\alpha$ phospho-Ser167 were similar between these two groups. Thus, the downstream signaling events and clinical role of PIK3CA mutations in premenopausal ER-positive breast cancer require further elucidation. The mechanisms of development and biological characteristics of ER-positive breast cancer might therefore differ according to menopausal status $[12,26]$.

In postmenopausal breast cancer, we classified PIK3CA wild-type breast tumors into 4 types and 
Table 7: Correlation between combined PIK3CA-pAKT-pER status and clinicopathological factors and prognosis in postmenopausal women

$P I K 3 C A$ wild-type $(n=73)$

PIK3CA mutant $(n=71)$

\begin{tabular}{|c|c|c|c|c|c|c|c|}
\hline Type & Type A & Type B & Type C & Type D & Type E & Type F & Type G \\
\hline pAKT & high & high & low & low & high & low & low \\
\hline pER & low & high & low & high & low/high & low & high \\
\hline No. of patients & $8(11 \%)$ & $13(18 \%)$ & $26(36 \%)$ & $26(36 \%)$ & $9(13 \%)$ & $21(30 \%)$ & $41(58 \%)$ \\
\hline $\begin{array}{l}\text { Age (years), mean } \pm \\
\text { SD (range) }\end{array}$ & $\begin{array}{c}63.8 \pm 8.0 \\
(52-78)\end{array}$ & $\begin{array}{c}59.4 \pm 6.6 \\
(50-74)\end{array}$ & $\begin{array}{c}62.3 \pm 9.4 \\
(42-80)\end{array}$ & $\begin{array}{c}62.4 \pm 7.8 \\
(50-77)\end{array}$ & $\begin{array}{l}57.2 \pm 6.8^{d} \\
(47-71)\end{array}$ & $\begin{array}{c}64.4 \pm 5.9 \\
(52-74)\end{array}$ & $\begin{array}{c}65.0 \pm 9.0^{\mathrm{d}} \\
(48-84)\end{array}$ \\
\hline $\mathrm{BMI}$, mean $\pm \mathrm{SD}$ & $23.4 \pm 4.2$ & $23.2 \pm 2.4$ & $26.1 \pm 4.1$ & $24.0 \pm 5.3$ & $21.5 \pm 3.0$ & $25.3 \pm 4.2$ & $23.6 \pm 4.1$ \\
\hline $\begin{array}{l}\text { Tumor size }(\mathrm{T}) \text {, } \\
\text { median (range) }\end{array}$ & $2(1-3)$ & $1(1-2)$ & $2(1-3)$ & $1(1-2)$ & $1(1-3)$ & $1(1-3)^{\mathrm{e}}$ & $1(1-2)^{\mathrm{e}}$ \\
\hline $\begin{array}{l}\text { No. of positive } \\
\text { lymph nodes, } \\
\text { median (range) }\end{array}$ & $1(0-6)$ & $0(0-1)$ & $0(0-4)$ & $0(0-10)$ & $0(0-1)$ & $0(0-10)$ & $0(0-7)$ \\
\hline $\begin{array}{l}\text { Tumor grade, } \\
\text { median (range) }\end{array}$ & $3(2-3)^{\mathrm{a}}$ & $2(1-2)^{\mathrm{a}}$ & $2(1-3)$ & $2(1-3)$ & $2(1-2)$ & $2(1-3)$ & $2(1-3)$ \\
\hline $\begin{array}{l}\text { Ki67 LI (\%), } \\
\text { median (range) }\end{array}$ & $\begin{array}{c}18.8 \\
(6.8-39.8)\end{array}$ & $\begin{array}{c}19.5 \\
(3.5-52.7)\end{array}$ & $\begin{array}{c}9.1 \\
(2.0-31.7)\end{array}$ & $\begin{array}{c}11.0 \\
(2.0-31.4)\end{array}$ & $\begin{array}{c}5.5 \\
(2.0-27.6)\end{array}$ & $\begin{array}{c}11.5 \\
(0.1-34.1)\end{array}$ & $\begin{array}{c}7.0 \\
(0.4-35.3)\end{array}$ \\
\hline $\begin{array}{l}\text { ER }(\%), \\
\text { median (range) }\end{array}$ & $\begin{array}{c}90 \\
(20-100)\end{array}$ & $\begin{array}{c}90 \\
(10-100)\end{array}$ & $\begin{array}{c}80 \\
(10-100)\end{array}$ & $\begin{array}{c}90 \\
(20-100)\end{array}$ & $\begin{array}{c}60 \\
(50-100)\end{array}$ & $\begin{array}{c}90 \\
(20-100)^{\mathrm{f}}\end{array}$ & $\begin{array}{c}90 \\
(40-100)^{\mathrm{f}}\end{array}$ \\
\hline $\begin{array}{l}\operatorname{PgR}(\%), \\
\text { median (range) }\end{array}$ & $\begin{array}{c}20 \\
(0-100)\end{array}$ & $\begin{array}{c}5 \\
(0-80)^{\mathrm{b}}\end{array}$ & $\begin{array}{c}30 \\
(0-100)^{\mathrm{b}}\end{array}$ & $\begin{array}{c}10 \\
(0-70)\end{array}$ & $\begin{array}{c}5 \\
(0-30)\end{array}$ & $\begin{array}{c}20 \\
(0-90)\end{array}$ & $\begin{array}{c}20 \\
(0-100)\end{array}$ \\
\hline $\begin{array}{l}\mathrm{AR}(\%), \text { mean } \pm \mathrm{SD} \\
\text { (range) }\end{array}$ & $\begin{array}{c}31.3 \pm 25.7 \\
(5-80)\end{array}$ & $\begin{array}{c}42.5 \pm 32.6 \\
(1-95)\end{array}$ & $\begin{array}{l}23.4 \pm 21.8 \\
\quad(0-80)\end{array}$ & $\begin{array}{l}38.3 \pm 32.5 \\
\quad(0-95)\end{array}$ & $\begin{array}{c}45.2 \pm 39.6 \\
(1-95)\end{array}$ & $\begin{array}{c}29.8 \pm 28.0^{\mathrm{g}} \\
(0-95)\end{array}$ & $\begin{array}{c}50.2 \pm 34.0^{g} \\
\quad(1-100)\end{array}$ \\
\hline $\begin{array}{l}\text { VDR }(\%), \\
\text { median (range) }\end{array}$ & $\begin{array}{c}7.5 \\
(0-50)\end{array}$ & $\begin{array}{c}20 \\
(0-50)^{\mathrm{c}}\end{array}$ & $\begin{array}{c}5 \\
(0-30)^{\mathrm{c}}\end{array}$ & $\begin{array}{c}15 \\
(0-80)\end{array}$ & $\begin{array}{c}20 \\
(0-50)\end{array}$ & $\begin{array}{c}25 \\
(0-40)\end{array}$ & $\begin{array}{c}15 \\
(0-50)\end{array}$ \\
\hline \multicolumn{8}{|c|}{ No. of patients with recurrence } \\
\hline within 2 years & $3(38 \%)$ & 0 & $2(8 \%)$ & 0 & 0 & $1(5 \%)$ & 0 \\
\hline within 5 years & $4(50 \%)$ & $2(15 \%)$ & $3(12 \%)$ & 0 & 0 & $2(10 \%)$ & 0 \\
\hline within 10 years & $4(50 \%)$ & $3(23 \%)$ & $4(15 \%)$ & $2(8 \%)$ & 0 & $3(14 \%)$ & 0 \\
\hline
\end{tabular}

LI: labeling index; pAKT: AKT phospho-Ser473; pER: ER $\alpha$ phospho-Ser167.

${ }^{\mathrm{a}} P=0.0083$ by Steel's test. ${ }^{\mathrm{b}} P=0.047$ by Steel's test. ${ }^{\mathrm{c}} P=0.032$ by Steel's test. ${ }^{\mathrm{d}} P=0.0095$ by Dunnett's test. ${ }^{\mathrm{e}} P=0.0094$ by Steel's test. ${ }^{\mathrm{f}} P=0.023$ by Steel's test. ${ }^{\mathrm{g}} P=0.024$ by Dunnett's test.

$P I K 3 C A$ mutant tumors into 3 types according to the phosphorylation status of AKT Ser473 and ER $\alpha$ Ser167. This revealed that a half of the patients who had PIK3CA wild-type tumors with high AKT phospho-Ser473 and low ER $\alpha$ phospho-Ser167 relapsed within 5 years after the initial treatment (Type A). The tumors of this type were of a higher grade, and none of the Type A patients relapsed 5 years after the initial treatment. Therefore, PIK3CA wildtype tumors with high AKT phospho-Ser473 and low ER $\alpha$ phospho-Ser167 might be luminal B-like tumors with relatively rapid growth and aggressive phenotype. AKT1 activation has been linked to endocrine resistance [27], and treatment of early breast cancer with mTOR inhibitors reduces AKT signaling and proliferation [28, 29]. 
Standard adjuvant chemotherapy including anthracyclins and/or taxanes as well as endocrine therapy might not be sufficient to block early recurrence in PIK3CA wildtype tumors with high AKT phospho-Ser473 and low ER $\alpha$ phospho-Ser167. Therefore, other strategies, such as the inclusion of inhibitors of other signal transduction pathways might improve survival for women with luminal B-like breast cancer subtype in the absence of PIK3CA mutation.

Our study showed that $P I K 3 C A$ mutant tumors with low AKT phospho-Ser473 and high ER $\alpha$ phospho-Ser167 (Type G) was the most frequent type in postmenopausal women, and almost $30 \%$ of postmenopausal ER-positive, HER2-negative breast cancer were classified as this type. All of the patients in Type $\mathrm{G}$ are currently disease-free. Thus, PIK3CA mutant tumors with low AKT phosphoSer473 and high ER $\alpha$ phospho-Ser167 appear to be of the luminal A-like subtype, and are highly endocrineresponsive. We previously demonstrated that high ER $\alpha$ phospho-Ser167 levels were associated with an improved disease-free and overall survival [9], and that this marker correlated with a better response to endocrine therapy and longer survival after relapse [10]. Thus, phosphorylation of ER $\alpha$ Ser167 might occur frequently in response to estrogen and be predictive of response to endocrine therapy in postmenopausal ER-positive breast cancer. Evaluation of ER $\alpha$ Ser167 phosphorylation, as well as PIK3CA mutation status, might be helpful in identifying patients who are likely to benefit from endocrine therapy alone versus those who are not.

In conclusion, we demonstrate that almost 50\% of ER-positive, HER2-negative early invasive ductal carcinoma of the breast had mutations of PIK3CA gene. $P I K 3 C A$ tumor mutations were associated with significant better disease-free survival in postmenopausal women. Furthermore, low levels of AKT phospho-Ser473 and high levels of ER $\alpha$ phospho-Ser167 correlated with improved

A

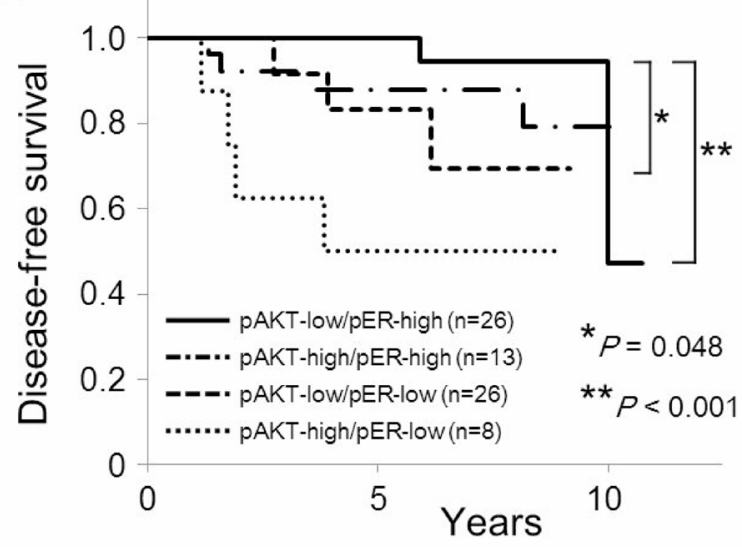

survival in postmenopausal women. We therefore suggest that ER $\alpha$ activation, in addition to $P I K 3 C A$ mutation, should be considered as a predictor of highly endocrine-responsive tumors and improved prognosis in postmenopausal ER-positive early breast cancer.

\section{MATERIALS AND METHODS}

\section{Patients and breast cancer tissues}

A total of 214 women treated for Stage I to III breast cancer between 2004 and 2010 at Hokkaido University Hospital were recruited to this study (Table 1). The study protocol was approved by the institutional review board and conformed to the guidelines of the 1996 Declaration of Helsinki. Written informed consent for the use of surgically resected tumor tissues was provided by all patients prior to treatments. The samples were chosen from a continuous series of ER-positive, HER2-negative invasive ductal carcinoma of the breast. All patients had undergone mastectomy or lumpectomy. Tumor samples were obtained during surgery. Patients received adequate endocrine or chemotherapy as adjuvant therapy. Patients treated with neoadjuvant chemotherapy were excluded. Patients received adjuvant endocrine therapy (tamoxifen \pm luteinizing hormone-releasing hormone agonist for premenopausal women and aromatase inhibitors for postmenopausal women), and patients who had positive results of axillary lymph node dissection received adjuvant chemotherapy including anthracyclines and/or taxanes, as well as adjuvant endocrine therapy.

\section{Immunohistochemical (IHC) analysis}

One 4- $\mu \mathrm{m}$ section of each submitted paraffin block was stained first with hematoxylin-eosin to verify that an adequate number of carcinoma cells were present and that

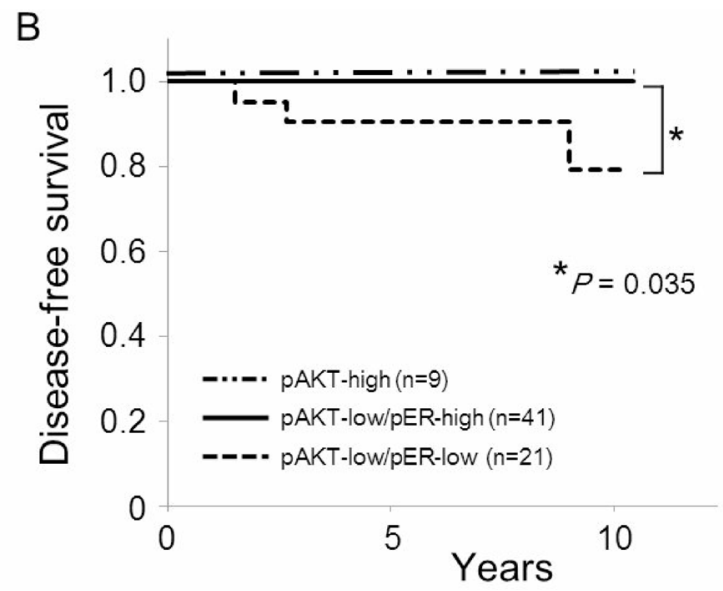

Figure 3: Kaplan-Meir curves of the effect of phosphorylation of AKT Ser473 and ERa Ser167 by PIK3CA mutation status on disease-free survival in postmenopausal women. (A) Disease-free survival according to phosphorylation status of AKT Ser473 and ER $\alpha$ Ser167 in PIK3CA wild-type tumors. (B) Disease-free survival according to phosphorylation status of AKT Ser473 and $\mathrm{ER} \alpha \mathrm{Ser} 167$ in PIK3CA mutant tumors. 
the fixation quality was adequate for IHC analysis. Serial sections $(4 \mu \mathrm{m})$ were then prepared from selected blocks and float-mounted on adhesive-coated glass slides for IHC. Details of antibodies and evaluation methods are described in Table 2 [26], and representative images of staining for AR, VDR, AKT phospho-Ser473, and ER $\alpha$ phosphoSer167 are shown in Figure 1 . Tumors with $\geq 1 \%$ of cells showing positive nuclear staining for the expression of ER were evaluated as ER-positive. To determine the level of HER2 expression, the membrane staining pattern was estimated and scored on a scale of 0 to $3+$. Tumors with a score of $2+$ were tested for gene amplification by FISH using the PathVysion assay (Vysis, Abbott Laboratories, Abbott Park, IL, USA). A ratio of HER2 gene/chromosome $17>2.2$ was considered positive. Tumors were considered HER2-positive if IHC staining scored 3+ or FISH was positive [30]. HER2-positive tumors were excluded from this study. The Ki67 labeling index (LI) was assessed as the percentage of tumor cells showing definite nuclear staining among >1000 invasive tumor cells analyzed using a NanoZoomer 2.0-HT (Hamamatsu photonics, Hamamatsu, Japan) for slide scanning and Tissue Studio (Definiens, Munich, Germany) for automated scoring [31]. If there were clear hot spots, data from these areas were assessed. Phosphorylation of AKT Ser473 was quantified as the percentage of cells with positive cytoplasmic staining. An intensity score represented the average intensity of the positive cells as follows: 0 (none), 1 (weak), 2 (intermediate), and 3 (strong). The proportion of positive cells and an intensity score were then multiplied to obtain a total score, which could range from 0 to 300 .

\section{DNA isolation and PIK3CA mutation analysis}

Genomic DNA was extracted from formalinfixed paraffin-embedded tumor blocks using the cobas $^{\circledR}$ DNA Sample Preparation Kit (Roche Molecular Systems, Pleasanton, USA) [32]. Four to eight pieces of deparaffinized $10 \mu \mathrm{m}$ section were used for the extraction process. When tumor cells constituted less than $20 \%$ of the specimens, the tumor area was macro-dissected before DNA extraction. The amount of genomic DNA was spectrophotometrically determined (NanoDrop 2000c, Thermo Fisher Scientific, Waltham, USA) and adjusted to a fixed concentration before use for amplification/ detection.

Mutations in the PIK3CA gene were detected using the cobas $^{\circledR}$ PIK3CA Mutation Test (Roche Molecular Systems) [32]. This test uses a pool of primers divided into three different mixes for each sample and control that define specific base-pair (bp) sequences that range from 85 to 155 bp in exons $1,4,7,9$, and 20 of the PIK3CA gene. An additional primer pair, targeting a conserved 167 bp region in $P I K 3 C A$ exon 3, provided a full process control. A derivative of Thermus species Z05-AS1 DNA-polymerase is utilized for amplification. Selective amplification of target nucleic acid from the sample is achieved in the $\operatorname{cobas}^{\circledR}$ PIK3CA Mutation Test by the use of AmpErase (uracil-N-glycosylase) enzyme and deoxyuridine triphosphate (dUTP). The test is designed to detect R88Q in exon 1, N345K in exon 4, C420R in exon 7, E542K, E545X (E545A, E545D, E545G, and E545K), and Q546X (Q546E, Q546K, Q546L, and Q546R) in exon 9, and M1043I, H1047X (H1047L, H1047R, and H1047Y), and G1049R in exon 20, when the mutation is present at levels of $5 \%$ or greater. All of the seventeen mutations are missense mutations. The target DNA was amplified and analyzed on the $\operatorname{cobas}^{\circledR} \mathrm{z} 480$ analyzer (cobas ${ }^{\circledR} 4800$ System, Roche). In cases of invalid results, specimen testing was repeated. An invalid result from retesting was excluded from the analysis as an invalid sample.

\section{Statistical analysis}

Mann-Whitney $U$ tests, Fisher's exact test and the chi-square test were used to compare expression and phosphorylation of biological markers between pre- and postmenopausal women, and to compare clinicopathological and biological factors between $P I K 3 C A$ wild-type and mutant tumors. Estimation of disease-free survival was performed using the Kaplan-Meier method, and differences between survival curves were assessed using the log-rank test. Cox's proportional hazards model was used for univariate and multivariate analyses of prognostic values. In order to determine whether the clinicopathological and biological factors were different dependent on PIK3CA status, we first evaluated the homogeneity of variance using Bartlett's test. Dunnett's test was then used for analyzing homogenous data, and Steel's test was used for analyzing heterogeneous data. Statistical analysis was performed using Excel software (Excel 2013 for Windows, Microsoft corp., Albuquerque, USA).

\section{Abbreviations}

ER: estrogen receptor; Ser: serine; PgR: progesterone receptor; HER2: human epidermal growth factor receptor type 2; AR: androgen receptor; VDR: vitamin D receptor; PIK3CA: phosphatidylinositol-4,-5-bisphosphate 3-kinase catalytic subunit alpha; PI3K: phosphatidylinositol 3-kinase; IHC: immunohistochemistry; LI: labeling index.

\section{Author contributions}

NI carried out experiments, analyzed the data, and participated in manuscript writing. $\mathrm{MB}$ and $\mathrm{KH}$ provided tissue samples. $\mathrm{YH}$ and $\mathrm{KT}$ carried out mutation experiments. $\mathrm{HO}, \mathrm{KCH}$ and $\mathrm{YM}$ carried out immunostaining experiments. HY conceived of the study and participated in manuscript writing. All authors read and approved the final manuscript. 


\section{ACKNOWLEDGMENTS}

The authors thank Mrs. Mikiko Sato and Mrs. Yuko Hirano for their excellent technical assistance.

\section{CONFLICTS OF INTEREST}

Yutaka Hatanaka received research funding from Roche Diagnostics K.K. Kenichi Togashi is an employee of Roche Diagnostics K.K. The other authors declare that they have no conflict of interest.

\section{FUNDING}

This work was supported in part by Grants-inAid for Scientific Research from Japan Society for the Promotion of Science.

\section{REFERENCES}

1. Davies C, Godwin J, Gray R, Clarke M, Cutter D, Darby S, McGale P, Pan HC, Taylor C, Wang YC, Dowsett M, Ingle J, Peto R. Relevance of breast cancer hormone receptors and other factors to the efficacy of adjuvant tamoxifen: patientlevel meta-analysis of randomised trials. Lancet. 2011; 378:771-784.

2. Dowsett M, Forbes JF, Bradley R, Ingle J, Aihara T, Bliss J, Boccardo F, Coates A, Coombes RC, Cuzick J, Dubsky P, Gnant M, Kaufmann M, et al. Aromatase inhibitors versus tamoxifen in early breast cancer: patient-level meta-analysis of the randomised trials. Lancet. 2015; 386:1341-1352.

3. Yamashita H, Ogiya A, Shien T, Horimoto Y, Masuda N, Inao T, Osako T, Takahashi M, Endo Y, Hosoda M, Ishida N, Horii R, Yamazaki K, et al. Clinicopathological factors predicting early and late distant recurrence in estrogen receptor-positive, HER2-negative breast cancer. Breast Cancer. 2016; 23:830-843.

4. Cancer Genome Atlas Network. Comprehensive molecular portraits of human breast tumours. Nature. 2012; 490:61-70.

5. Pereira B, Chin SF, Rueda OM, Vollan HK, Provenzano E, Bardwell HA, Pugh M, Jones L, Russell R, Sammut SJ, Tsui DW, Liu B, Dawson SJ, et al. The somatic mutation profiles of 2,433 breast cancers refines their genomic and transcriptomic landscapes. Nat Commun. 2016; 7:11479.

6. Forbes SA, Bindal N, Bamford S, Cole C, Kok CY, Beare D, Jia M, Shepherd R, Leung K, Menzies A, Teague JW, Campbell PJ, Stratton MR, et al. COSMIC: mining complete cancer genomes in the Catalogue of Somatic Mutations in Cancer. Nucleic Acids Res. 2011; 39:D945-950.

7. Pang B, Cheng S, Sun SP, An C, Liu ZY, Feng X, Liu GJ. Prognostic role of PIK3CA mutations and their association with hormone receptor expression in breast cancer: a metaanalysis. Sci Rep. 2014; 4:6255.
8. Mukohara T. PI3K mutations in breast cancer: prognostic and therapeutic implications. Breast Cancer (Dove Med Press). 2015; 7:111-123.

9. Yamashita H, Nishio M, Toyama T, Sugiura H, Kondo N, Kobayashi S, Fujii Y, Iwase H. Low phosphorylation of estrogen receptor alpha (ERalpha) serine 118 and high phosphorylation of ERalpha serine 167 improve survival in ER-positive breast cancer. Endocr Relat Cancer. 2008; 15:755-763.

10. Yamashita H, Nishio M, Kobayashi S, Ando Y, Sugiura H, Zhang Z, Hamaguchi M, Mita K, Fujii Y, Iwase H. Phosphorylation of estrogen receptor alpha serine 167 is predictive of response to endocrine therapy and increases postrelapse survival in metastatic breast cancer. Breast Cancer Res. 2005; 7:R753-764.

11. Anbalagan M, Rowan BG. Estrogen receptor alpha phosphorylation and its functional impact in human breast cancer. Mol Cell Endocrinol. 2015; 418:264-272.

12. Yamashita H. Tumor biology in estrogen receptor-positive, human epidermal growth factor receptor type 2-negative breast cancer: Mind the menopausal status. World J Clin Oncol. 2015; 6:220-224.

13. Santagata S, Thakkar A, Ergonul A, Wang B, Woo T, Hu R, Harrell JC, McNamara G, Schwede M, Culhane AC, Kindelberger D, Rodig S, Richardson A, et al. Taxonomy of breast cancer based on normal cell phenotype predicts outcome. J Clin Invest. 2014; 124:859-870.

14. Anestis A, Karamouzis MV, Dalagiorgou G, Papavassiliou AG. Is androgen receptor targeting an emerging treatment strategy for triple negative breast cancer? Cancer Treat Rev. 2015; 41:547-553.

15. Bozovic-Spasojevic I, Zardavas D, Brohee S, Ameye L, Fumagalli D, Ades F, de Azambuja E, Bareche Y, Piccart M, Paesmans M, Sotiriou C. The Prognostic Role of Androgen Receptor in Patients with Early-Stage Breast Cancer: A Meta-analysis of Clinical and Gene Expression Data. Clin Cancer Res. 2017; 23:2702-2712.

16. Castellano I, Allia E, Accortanzo V, Vandone AM, Chiusa L, Arisio R, Durando A, Donadio M, Bussolati G, Coates AS, Viale G, Sapino A. Androgen receptor expression is a significant prognostic factor in estrogen receptor positive breast cancers. Breast Cancer Res Treat. 2010; 124:607-617.

17. Gonzalez-Angulo AM, Stemke-Hale K, Palla SL, Carey M, Agarwal R, Meric-Berstam F, Traina TA, Hudis C, Hortobagyi GN, Gerald WL, Mills GB, Hennessy BT. Androgen receptor levels and association with PIK3CA mutations and prognosis in breast cancer. Clin Cancer Res. 2009; 15:2472-2478.

18. Al-Azhri J, Zhang Y, Bshara W, Zirpoli G, McCann SE, Khoury T, Morrison CD, Edge SB, Ambrosone CB, Yao S. Tumor Expression of Vitamin D Receptor and Breast Cancer Histopathological Characteristics and Prognosis. Clin Cancer Res. 2017; 23:97-103. 
19. Ditsch N, Toth B, Mayr D, Lenhard M, Gallwas J, Weissenbacher T, Dannecker C, Friese K, Jeschke U. The association between vitamin $\mathrm{D}$ receptor expression and prolonged overall survival in breast cancer. J Histochem Cytochem. 2012; 60:121-129.

20. Isakoff SJ, Engelman JA, Irie HY, Luo J, Brachmann SM, Pearline RV, Cantley LC, Brugge JS. Breast cancerassociated PIK3CA mutations are oncogenic in mammary epithelial cells. Cancer Res. 2005; 65:10992-11000.

21. Kang S, Bader AG, Vogt PK. Phosphatidylinositol 3-kinase mutations identified in human cancer are oncogenic. Proc Natl Acad Sci U S A. 2005; 102:802-807.

22. Bader AG, Kang S, Vogt PK. Cancer-specific mutations in PIK3CA are oncogenic in vivo. Proc Natl Acad Sci U S A. 2006; 103:1475-1479.

23. Baselga J, Im SA, Iwata H, Cortes J, De Laurentiis M, Jiang Z, Arteaga CL, Jonat W, Clemons M, Ito Y, Awada A, Chia S, Jagiello-Gruszfeld A, et al. Buparlisib plus fulvestrant versus placebo plus fulvestrant in postmenopausal, hormone receptor-positive, HER2-negative, advanced breast cancer (BELLE-2): a randomised, double-blind, placebo-controlled, phase 3 trial. Lancet Oncol. 2017; 18:904-916.

24. Loi S, Haibe-Kains B, Majjaj S, Lallemand F, Durbecq V, Larsimont D, Gonzalez-Angulo AM, Pusztai L, Symmans WF, Bardelli A, Ellis P, Tutt AN, Gillett CE, et al. PIK3CA mutations associated with gene signature of low mTORC1 signaling and better outcomes in estrogen receptorpositive breast cancer. Proc Natl Acad Sci U S A. 2010; 107:10208-10213.

25. Sabine VS, Crozier C, Brookes CL, Drake C, Piper T, van de Velde CJ, Hasenburg A, Kieback DG, Markopoulos C, Dirix L, Seynaeve C, Rea DW, Bartlett JM. Mutational analysis of PI3K/AKT signaling pathway in tamoxifen exemestane adjuvant multinational pathology study. J Clin Oncol. 2014; 32:2951-2958.

26. Hosoda M, Yamamoto M, Nakano K, Hatanaka KC, Takakuwa E, Hatanaka Y, Matsuno Y, Yamashita H. Differential expression of progesterone receptor, FOXA1,
GATA3, and p53 between pre- and postmenopausal women with estrogen receptor-positive breast cancer. Breast Cancer Res Treat. 2014; 144:249-261.

27. Spears M, Cunningham CA, Taylor KJ, Mallon EA, Thomas JS, Kerr GR, Jack WJ, Kunkler IH, Cameron DA, Chetty U, Bartlett JM. Proximity ligation assays for isoform-specific Akt activation in breast cancer identify activated Akt1 as a driver of progression. J Pathol. 2012; 227:481-489.

28. Sabine VS, Sims AH, Macaskill EJ, Renshaw L, Thomas JS, Dixon JM, Bartlett JM. Gene expression profiling of response to mTOR inhibitor everolimus in pre-operatively treated post-menopausal women with oestrogen receptorpositive breast cancer. Breast Cancer Res Treat. 2010; 122:419-428.

29. Macaskill EJ, Bartlett JM, Sabine VS, Faratian D, Renshaw L, White S, Campbell FM, Young O, Williams L, Thomas JS, Barber MD, Dixon JM. The mammalian target of rapamycin inhibitor everolimus (RAD001) in early breast cancer: results of a pre-operative study. Breast Cancer Res Treat. 2011; 128:725-734.

30. Wolff AC, Hammond ME, Schwartz JN, Hagerty KL, Allred DC, Cote RJ, Dowsett M, Fitzgibbons PL, Hanna WM, Langer A, McShane LM, Paik S, Pegram MD, et al. American Society of Clinical Oncology/College of American Pathologists guideline recommendations for human epidermal growth factor receptor 2 testing in breast cancer. J Clin Oncol. 2007; 25:118-145.

31. Yamamoto M, Hosoda M, Nakano K, Jia S, Hatanaka KC, Takakuwa E, Hatanaka Y, Matsuno Y, Yamashita H. p53 accumulation is a strong predictor of recurrence in estrogen receptor-positive breast cancer patients treated with aromatase inhibitors. Cancer Sci. 2014; 105:81-88.

32. Cossu-Rocca P, Orru S, Muroni MR, Sanges F, Sotgiu G, Ena S, Pira G, Murgia L, Manca A, Uras MG, Sarobba MG, Urru S, De Miglio MR. Analysis of PIK3CA Mutations and Activation Pathways in Triple Negative Breast Cancer. PLoS One. 2015; 10:e0141763. 